\title{
REFLEXÕES SOBRE A QUESTÃO DO NOME PRÓPRIO NA TOPONÍMIA
}

Márcia Zamariano

\begin{abstract}
RESUMO
Um aspecto importante a ser focalizado em um estudo toponímico é a natureza do nome próprio. Tema abordado por diferentes correntes do pensamento, desde Aristóteles, suscita uma investigação que não se encerra em uma disciplina específica. Assim, buscamos realizar um estudo acerca da construção do conceito de nome próprio nas perspectivas de correntes filosóficas e pesquisadores da linguística.
\end{abstract}

PALAVRAS-CHAVE: nome próprio, toponímia, antroponímia.

\section{Introdução}

linguagem é a expressão do pensamento, e isto só é possível porque o homem se expressa por palavras e com elas se comunica, abstrai e in-

terpreta a realidade das coisas que existem, inventa outras e lhes atribui nomes, explicando em que condiçóes elas chegam a se manifestar. Ao mesmo tempo, nomeando, o ser humano expressa sua própria essência espiritual no nome e, quando no cotidiano designa as coisas, manifesta então a sua essência linguística.

Embora por vezes seja dificultosa toda tentativa de explicação das fontes geradoras dos nomes de lugares e de acidentes geográficos, a Toponímia é a área das Ciências Humanas que tem como objeto de estudo essa categoria de nomes. Ela compóe junto com a Antroponímia (estudo dos nomes de pessoas) a Onomástica - ciência que estuda os nomes próprios. Um tema a ser considerado em um estudo com dados toponímicos é a própria definição de signo 
linguístico, sobretudo a natureza do nome próprio, questão teórica que tem se constituído, ao longo do tempo, numa grande preocupação de estudiosos da Filosofia, da Lógica e da Linguística. Essa discussão acerca do estatuto do nome próprio abrange sua definição, as classificações propostas por lógicos, filósofos e linguistas e a denominação utilizada por eles em seus estudos.

Nesse particular, é preciso considerar que a questão do nome já era discutida na Grécia, embora, naquela época, ainda não houvesse a distinção entre o conceito de nome próprio em oposição ao nome comum, nos moldes em que é feita na atualidade: a definição de onoma servia para se referir às denominaçôes de seres individuais, atividades humanas e objetos. Atualmente, é prática habitual dar nome às pessoas. Por isso, normalmente, não se costuma refletir muito sobre o fato de esse nome ter sido atribuído ao indivíduo pelos seus próprios pais. É importante lembrar que o nome estabelece com o indivíduo que o recebeu um vínculo de natureza psicológica, que vai substituí-lo na sua representatividade dentro do grupo social ao qual pertence.

A Toponímia possui como eixo central de seus estudos o signo toponímico (nome próprio de lugar - topônimo), que é o signo linguístico na função de indicador ou identificador de um espaço (acidente) geográfico. $\mathrm{O}$ nome possui função de identificação, isto é, tudo que existe tem sua nomenclatura, terminologia, que envolve um sistema de palavras, qualidades para determinar fatos, fenômenos ou objetivos, com o intuito de determinar seu real significado e suas relaçóes com o universo conhecido.

Em se tratando do signo toponímico, apesar de estar inserido entre os demais signos no sistema linguístico, há algumas particularidades que o distinguem dos demais nomes próprios.

Ullmann ${ }^{1}$, por exemplo, esclarece que "a função específica de um nome próprio é identificar e não significar”. Um nome próprio, particularmente o topônimo, além de designar, significa e pode, mediante a análise da sua estrutura:

fornecer elementos para esclarecer muitos aspectos referentes à história política, econômica e sociocultural de uma regiāo. Desta forma, o papel do signo toponímico ultrapassa o nível apenas da

1 ULLMANN, Stephen. Semântica: uma introdução à ciência do significado. 5. ed. Lisboa: Fundação Calouste Gulbenkian, 1987. p. 155. 
identificação, servindo, pois de referência para o entendimento de aspectos da realidade em que está inserido (ISQUERDO) ${ }^{2}$.

Partindo dessas considerações, fica evidente que o signo linguístico se reserva à arbitrariedade, enquanto o signo toponímico à motivação: o que os diferencia é a função significativa quando a toponímia os transforma em seu objeto de estudo.

No âmbito dessa discussão, Aguilera $^{3}$ pondera que "a nomeação dos acidentes geográficos não é feita aleatoriamente pelo homem, mas o faz movido por alguma impressão sensorial e/ou sentimental que o acometa no momento da denominação". Assim, o mecanismo da nomeação, por meio das influências externas ou subjetivas, transparece em topônimos das mais diversas origens e procedências, confirmando-se o que destaca Dick ${ }^{4}$ : "nome e nomeador pertencem a um só conjunto, são elementos da mesma origem, unidos pelo ato da nomeaçáo”.

\section{O signo linguístico}

Desde a Antiguidade, nas mais diferentes culturas, estudiosos da Filosofia, da Lógica e da Linguística buscam a melhor definição e caracterização do signo linguístico (ou a natureza da palavra). Entretanto, o problema permanece obscuro, gerando discussão, tanto no que diz respeito à sua definição, quanto às classificaçôes propostas e quanto, ainda, à denominação utilizada.

Com relação ao esse tema, Schaff argumenta:

o que impressiona é a tremenda ambigüidade do termo signo, tanto na linguagem comum como nas tentativas científicas de conferir precisão aos termos. Outro fator importante é a marcada vagueza e mesmo arbitrariedades das distinçôes terminológicas entre "signo", "índice", "símbolo", "sinal”, etc5.

2 ISQUERDO, Aparecida Negri. "A Toponímia como signo de representação de uma realidade”. Fronteiras: Revista de História. 2: jul./dez:31 - 32, Campo Grande, 1997, p. 31- 32.

3 AGUILERA, Vanderci de Andrade. "Taxionomia de Topônimos: Problema sem solução?” Revista SIGNUM: Estudos da Linguagem, 2:125, Londrina, 1999, p. 125.

4 DICK, Maria Vicentina de Paula do Amaral. A motivação toponímica e a realidade brasileira. São Paulo: Ediçôes Arquivo do Estado de Sáo Paulo, 1990 a. p. 60.

5 SCHAFF, Adam. Introdução à semântica. Rio de Janeiro: Civilização Brasileira, 1968. p. 167. 
No tocante à natureza específica do signo verbal, o mesmo autor destaca:

ele aparece em duas significaçóes diferentes: i) signo verbal significa o som (no sentido de vibração acústica ou imagem fônica) ao qual uma significação definida está ligada de um modo qualquer; ii) signo verbal - é o todo específico composto de som-e-significação, característico de entidades realmente existentes na linguagem fônica ${ }^{6}$.

Entre aqueles que se dedicaram aos estudos da linguagem, destaca-se Ferdinand de Saussure, linguista que, no início do século XX, destacou a arbitrariedade do signo e a linearidade do significante como características fundamentais do signo linguístico, definindo a língua como "um sistema de signos que exprimem ideias" e que funciona devido a um contrato social entre falantes de uma mesma língua (SAUSSURE) ${ }^{7}$. Saussure considera o signo linguístico como "uma entidade psíquica de duas faces", que estão "intimamente unidos e um reclama o outro", como o representado pela figura a seguir"

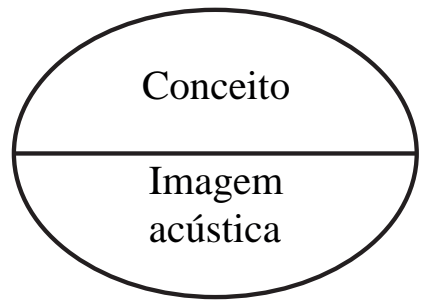

Nessa perspectiva, Saussure concebe o signo como a união de um conceito e de uma imagem acústica. Em outras palavras, para Saussure, conceito é sinônimo de significado (plano das ideias), em oposição ao significante (plano da expressão) $)^{9}$.

$\mathrm{Na}$ teoria do mestre genebrino, o signo possui caráter arbitrário, pois, o conceito de signo "não deve dar a ideia de que o significado dependa da livre

6 Ibidem, p. 98.

7 SAUSSURE, Ferdinand de. Curso de linguistica geral. São Paulo: Cultrix; USP, 1969. p. 24.

8 Ibidem, p. 80.

9 Ibidem, p. 81. 
escolha do que fala [...] o significante é imotivado, isto é, arbitrário em relação ao significado, com o qual não tem nenhum laço natural na realidade" ${ }^{10}$.

Com relação ao signo linguístico, Dosse destaca que ele:

une não uma coisa a seu nome, mas um conceito a uma imagem acústica num vínculo arbitrário que remete à realidade, ao referente, para o exterior do campo de estudo [...] O signo só envolve, portanto, a relação entre significado (o conceito) e o significante (imagem acústica), com exclusão do referente ${ }^{11}$.

O fato de vários autores se basearem em fundamentos diferentes, ao classificar signos, resulta em tipologias baseadas em diversos princípios de divisão. Com relação à classificação dos signos, $S_{\text {chaff }}{ }^{12}$ destaca duas distinções: i) os signos dividem-se em naturais (índices, sintomas) e signos propriamente ditos (artificiais); ii) os signos propriamente ditos dividem-se em signos verbais (e seus substitutos escritos) e todos os outros signos. O resultado é demonstrado com o gráfico apresentado a seguir:

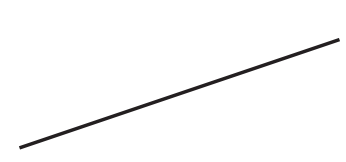

Signos naturais índices
SIGNOS

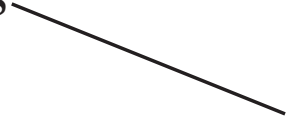

Signos artificiais ou

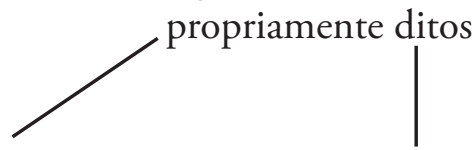

Signos propriamente ditos com expressão derivativa

Para Guiraud, no entanto, o signo é "um estímulo, isto é, uma substância sensível, cuja imagem mental está associada no nosso espírito à de outro estímulo

10 Ibidem, p. 83.

11 DOSSE, François. História do Estruturalismo: o campo do signo. Campinas: UNICAMP, 1993. p. 70.

12 SCHAFF, op.cit., p. 178-179. 
que ele tem por função evocar com vista a uma comunicação"13. Portanto, para o semanticista, há um vínculo entre o signo e algo que ele representa, ou seja, a realidade. Blikstein, por sua vez, considera que "o signo representaria a realidade extralinguística e, em princípio, é por meio dele que podemos conhecê-la"14.

É possível dizer que qualquer objeto, som, palavra capaz de representar uma outra coisa constitui signo. Para o homem comum, a noção de signo e suas relações não são importantes do ponto de vista teórico, mas ele os entende de maneira prática e precisa. A utilidade do signo vai além do que imaginamos, pois precisamos dele para entender o mundo, a nós mesmos e às pessoas com as quais mantemos relaçóes humanas.

\section{O signo toponímico}

$\mathrm{Na}$ busca do entendimento da significação e da representação, as questôes sobre o signo suscitam algumas reflexóes. Destaca-se que, ao servir-se de sua capacidade linguística para nomear os lugares, o homem estabelece algumas relaçóes: primeiro consigo próprio, ao demonstrar conhecer a realidade circundante e utilizar seu conhecimento para designar um local; e depois com seus interlocutores, pois, por meio do topônimo, transmite, com maior exatidão, o real significado que lhe atribuiu.

Para Isquerdo, o signo toponímico apresenta algumas especificidades que merecem consideração, e esclarece dois aspectos relevantes na sua constituição:

primeiramente, trata-se de nomes próprios cuja função específica é a de identificar e não de significar [...] cuja análise de sua estrutura pode fornecer elementos para esclarecer muitos aspectos referentes à história política, econômica e sociocultural de uma região [...]. Em segundo lugar, é preciso atentar para o fato de que toda nomeação, normalmente, é estimulada (ou até mesmo condicionada) por fatores inerentes à realidade circundante do denominador. ${ }^{15}$

13 GUIRAUD, Pierre. A Semântica. 4.ed. São Paulo: DIFEL, 1986. p. 35

14 BLIKSTEIN, Izidoro. Kaspar Hauser ou a fabricação da realidade. São Paulo: Cultrix/USP, 1998. p. 21.

15 ISQUERDO, op.cit. p. 31-32. 
No estudo da motivação do signo toponímico, Dick não desconsidera a relação que Saussure estabelece entre significado e significante, mas descarta a possibilidade da existência de signos imotivados (signos completamente desvinculados do significado), e mais que a arbitrariedade em língua diz respeito ao significante imotivado que é completamente desvinculado do significado ${ }^{16}$. No entanto, segundo a pesquisadora, ao se aplicar o mesmo princípio à toponímia, nota-se uma diversidade de aspectos:

o elemento linguístico comum, revestido, aqui, de função onomástica ou identificadora de lugares, integra um processo relacionante de motivação onde, muitas vezes, se torna possível deduzir conexôes hábeis entre o nome propriamente dito e a área por ele designada ${ }^{17}$.

Ainda conforme Dick, embora o topônimo em sua estrutura seja

uma forma de língua, ou um significante, animado por uma substância de conteúdo, da mesma maneira que todo e qualquer outro elemento do código em questáo, a funcionalidade de seu emprego adquire dimensão maior, marcando-o duplamente: o que era arbitrário, em termos de língua, transforma-se no ato de batismo de um lugar, em essencialmente motivado, náo sendo exagero afirmar ser essa uma das principais características do topônimo ${ }^{18}$.

A motivação é, pois, segundo a estudiosa, característica do signo, podendo-se falar em duplo aspecto da motivação toponímica. O primeiro aspecto é a intencionalidade, que anima o denominador, em um processo seletivo, para escolher um determinado nome para este ou aquele acidente geográfico. $\mathrm{O}$ segundo diz respeito à origem semântica da denominação, isto é, ao significado que ela evidencia, seja ele transparente ou opaco.

16 DICK, op. cit. p. 33.

17 Ibidem, p. 34.

18 DICK, Maria Vicentina de Paula do Amaral. Coletânea de estudos. 2.ed. São Paulo: Serviço de Artes Gráficas da Faculdade de Filosofia,Letras e Ciências Humanas,USP,1990 b. p. 18. 
A intencionalidade e a origem semântica da denominação, enquanto modalidades da motivação toponímica configuram perspectivas diacrônicas e sincrônicas no estudo da toponímia e acabam influindo na formalização das taxionomias dos nomes de lugares.

Nessas circunstâncias, o signo linguístico em função toponímica, ao representar a projeção aproximativa do real, torna clara a natureza semântica do seu significado. Poder-se-ia dizer que há uma relação unívoca entre os termos implicados que traduzem referências de cor, forma, tamanho, constituição natural, como em rio Grande, rio Pequeno, ribeirão $\underline{\text { Preto, }}$ córrego Branco, riacho Fundo, lagoa Rasa, ilha Comprida, aldeia Velha, Vila Nova, entre ou$\operatorname{tros}^{19}$. (grifos nossos)

Observa-se que, nos exemplos citados, os topônimos se aproximam do conceito de ícone ou de símbolo, sugeridos pela própria natureza dos acidentes nomeados, pondo em relevo outra das características do onomástico toponímico: a indicação precisa dos aspectos físicos ou antropo-culturais contidos na denominação ${ }^{20}$. Devemos considerar que, às vezes, não é possível prever com segurança a intencionalidade que norteou o ato da nomeação, seja pela ausência do denominador ou pela distância cronológica do tempo da denominação, isto é, do surgimento do nome.

\section{A natureza do nome próprio}

Outro aspecto focalizado como embasamento para o estudo dos dados toponímicos diz respeito à definição de signo linguístico, sobretudo a natureza do nome próprio, que tem se constituído, ao longo do tempo numa grande preocupação de estudiosos da Filosofia, da Lógica e da Linguística. No decorrer dos estudos sobre a linguagem, desde Aristóteles, grupos de autores discutem o tema sempre recorrente. Assim, pode um pesquisador perguntar: o nome próprio pertence ou não a um sistema linguístico particular? Existem diferenças entre o nome próprio e o nome comum? O nome próprio tem sentido além da denotação? Como os nomes próprios referem os objetos? Onde está o sentido de um nome? O nome próprio pode se constituir em objeto de

\footnotetext{
19 Ibidem, p. 19.

20 Ibidem, p. 18-19.
} 
reflexão com base em critérios semânticos? De todas essas inquirições sobre o estatuto do nome próprio, extraímos de determinante a necessidade de dar a esse objeto de estudo um tratamento diferenciado no interior do sistema linguístico. Para tanto, um trabalho que se dedique ao nome próprio suscita uma investigação que não se encerra em uma disciplina específica, visto que atravessa por campos teóricos distintos e as fronteiras que, aparentemente, isolam os campos, se dissolvem diante das primeiras reflexôes sobre esse tema.

A investigação sobre o nome próprio foi construída, de maneira predominante, por lógicos e filósofos. Platão é considerado como o primeiro pensador a estabelecer a distinção gramatical, dividindo as partes do discurso em dois componentes: nomes (ónoma) e verbos (rhéma); indicando o caminho para o estudo das proposiçóes, colocando a linguagem como objeto de estudo.

Em praticamente todos os seus diálogos, apresenta Sócrates questionando as pessoas que ele encontrava, pedindo-lhes que dissessem, definissem, explicassem o significado de "justiça", de "virtude", do "conhecimento", da "beleza", etc. É a partir desses questionamentos, que se delineia o "Crátilo", diálogo sobre a justeza dos nomes. Os três personagens que compóem a cena e assumem a palavra no diálogo são inspirados pelas figuras reais de Sócrates, de Hermógenes e de Crátilo. No "Crátilo", encontra-se a questão formulada por Platáo: se seriam os nomes fruto de uma convenção ou se designam aquilo que a coisa é, e, nesse caso, eles seriam atribuídos às coisas por um legislador que conhece a natureza dessas coisas. Sócrates, por sua vez, não apresenta, ao final, uma definição clara a favor das teses defendidas por Hermógenes, que vê os nomes como o resultado de uma convenção, nem das de Crátilo que defende que os nomes são estabelecidos em conformidade com a natureza das coisas. Conhecer os nomes significava conhecer as coisas, o que impossibilitava dizer coisas erradas (Crat. 429 d) ${ }^{21}$.

Platão considera ser suficiente chegar à conclusão de que não é por meio de seus nomes que devemos procurar conhecer ou estudar as coisas, mas, de preferência, por meio delas mesmas. Em linhas gerais, a obra de Platão possibilitou o entendimento de que o nome é a representação das ideias e das coisas.

21 PLATÃO. Crátilo. In: Teeteto - Crátilo. 3ed. rev. Belém: EDUFPA, 2001. p. 145-229. 
$\mathrm{Na}$ busca da construção de novos conhecimentos sobre o tema - nome próprio -, pode-se recolher da Lógica, da Filosofia da Linguagem e da Linguística as contribuiçóes de alguns autores que articulam esse tema e, a partir deles, apresentar as discussóes sobre o sentido do nome próprio, seu valor referencial.

Dentro do campo da Lógica no qual se percebe o interesse pela referência e pelo valor de verdade das proposiçóes, temos John Stuart Mill, o qual destaca:

todos os nomes são nomes de alguma coisa, real ou imaginaria, mas nem todas as coisas têm nomes próprios e individuais. Para alguns objetos individuais necessitamos e, conseqüentemente, separamos nomes distintos; há um nome para cada pessoa e para qualquer lugar notável ${ }^{22}$.

Mill prossegue, ponderando que, ao chamar uma criança de Paulo ou um cachorro de César, pode-se dizer que "deve ter havido alguma razão para lhes dar esses nomes em vez de qualquer outro". E mais, um homem poderia se chamar "João porque esse era o nome de seu pai; uma cidade poderia se chamar Dartmouth porque é situada na foz do rio Dart”. Entretanto, não há, na significação da palavra João, nada que indique que o pai da pessoa que possui esse nome tenha o mesmo nome; nem mesmo a palavra Dartmouth sugere que essa cidade esteja situada na foz do Dart. Conclui: "sempre que os nomes dados aos objetos contenham alguma informação sobre o objeto - ou seja, tenham propriamente alguma significação -, esta significação reside não no que eles denotam, mas no que conotam"23.

Ainda no campo da Lógica, o filósofo Gottlob Frege escreve, em 1892, o artigo "Über Sinn und Bedeutung" - "Sobre o Sentido e a Referência". De acordo com este filósofo, para que algo seja um nome próprio, é preciso que se refira a um objeto singular. Isso significa que algo é nome próprio se, e somente se, designa um particular e não mais que um, ou seja:

22 MILL, John Stuart. Sistema de Lógica Dedutiva e Indutiva. São Paulo: Abril Cultural, 1979. p. 96.

23 Ibidem, p. 101-103. 
o nome próprio deve ter pelo menos um sentido, senáo ele seria uma seqüência vazia de sons, ilegitimamente chamada de nome. Para uso científico, porém, deve-se exigir que também tenha uma referência, que designe ou nomeie um objeto. Assim o nome próprio se relaciona, mediante o sentido, e só mediante este, com o objeto ${ }^{24}$.

Ele assim resume a referência do nome próprio:

é o próprio objeto que por seu intermédio designamos: a representação que dele temos é inteiramente subjetiva; entre uma e outra está o sentido que, na verdade, não é tão subjetivo quanto à representação, mas que também não é o próprio objeto ${ }^{25}$.

Temos ainda Bertrand Russel ${ }^{26}$ que considera o nome próprio como o símbolo linguístico para a designação de particulares. E particulares são termos constituintes de relaçóes com fatos atômicos, e isso basta do ponto de vista lógico. Um fato interessante a se destacar é que, para Russell, a única espécie de palavra teoricamente capaz de representar um particular é um nome próprio, e declara que a questão completa dos nomes próprios é bastante curiosa. Em uma nota afirmativa, ele escreve: Nomes próprios = palavras para os particulares ${ }^{27}$.

Em meados do século XX, o filósofo Saul Kripke, delineia uma proposta denominada teoria causal da referência que motivou uma fortíssima polêmica em torno do nome próprio, centro de questóes filosóficas detalhadamente disputadas. Sua teoria parte de consideraçóes semânticas, como as relaçóes entre a linguagem e a realidade e, posteriormente, aplica os resultados obtidos no ataque ou defesa de certas teses filosóficas ${ }^{28}$. De acordo com Molino,

24 FREGE, Gottlob. Sobre o Sentido e a Referência. In: Lógica e Filosofia da Linguagem. São Paulo: Cultrix/USP, 1978. p. 64

25 Ibidem, p. 65.

26 RUSSELL, Bertrand. Lógica e Conhecimento. São Paulo: Abril Cultural, 1974. p. 77.

27 Ibidem, p. 77.

28 Disso provém à atenção que tem recebido essas teses e o interesse que têm despertado, constituindo-se uma referência obrigatória da filosofia contemporânea. 
c'est un autre problème de technique logique qui a conduit plus récemment Kripke à récuser l'analyse de Russell et à proposer une nouvelle conception du nom propre. On se souvient que Russell identifie noms propres et descriptions définies parce que leur comportement logique est analogue; de son côté, Kripke oppose noms propres et descriptions définies, parce que, dans l'analyse sémantique des systèmes de logique modale, les noms propres n’ont pás le même comportement que les descriptions définies ${ }^{29}$.

Granger ressalta que "S. Kripke a insisté, poursuivant les analyses de Donellan, sur la caractérisation du nom propre comme 'designateur rigide', ou seja, 'c'est-à-dire que le nom propre, indépendamment des prédicats attributes à l'objet qu'il designe, s'attacherait à cet objet comme à um point archimédien inconcussible". Esclarece que "Kripke considère assurément ici le nom comme propre dans la mesure où il désigne univoquement un individu, [...] ne saurait dépendre qu'en apparence de nos façons de le décrire" 30 .

Em sua obra, Kripke apresenta as argumentaçóes teóricas sobre designação por pressupostos que circulam no campo da Filosofia e que são discutidos por ele ao longo de seu texto, apontando seus pontos de concordância e discordância com os autores que discutem tais questóes ${ }^{31}$.

Em relação às descriçôes definidas, Kripke apresenta algumas consideraçóes envolvendo os conceitos de referência e necessidade, na Filosofia Analítica. Ao discutir a questão da nomeação, ele ressalta que por um nome ele toma "[...] a proper name, i.e., the name of a person, a city, a country, etc ${ }^{32}$." É importante assinalar que Kripke não inclui as descriçóes definidas ao utilizar o termo nome:

29 MOLINO, Jean. Le nom propre dans la langue. In: Revue Langages. Paris: Librairie Larousse, n. 66, juin, 1982, p.14.

30 GRANGER, Gilles. A quoi servent les noms propres? In: Revue Langages. Paris: Librairie Larousse, juin, n. 66, 1982, p. 31.

31 Naming and Necessity publicada em 1996. Na verdade, essa obra se situa na interface entre três disciplinas diferentes, a saber: a Lógica, a Filosofia da Linguagem e a Linguística.

32 KRIPKE, Saul. Naming and Necesity. In: Martinich, 1996, p. 254. 
We will use the term "name" so that its does not include definite descriptions of that sort, but only those things which in ordinary language would be called 'proper names'. If we want a common term to cover names and descriptions, we may use the term designator ${ }^{33}$.

Declara que é necessário recorrer à noção de identidade através dos mundos possíveis, para fazer a distinção entre 'designador rígido' e 'designador não-rígido ou acidental': "Let's call something a 'rigid designator' if in every possible world it designates the same object, a 'non rigid' or 'accidental designator' if that is not the case" 34 .

Para o autor, nomes próprios não são sinônimos de descriçóes definidas, pois essas possuem um conteúdo que diz algo acerca do objeto, enquanto os nomes não têm esse conteúdo, não indicam qualidades acerca de seus referentes, ou seja, não descrevem uma ou mais propriedades dos objetos ${ }^{35}$. Todavia, o quadro geral apresentado por ele é muito mais complexo do que parece, e as ideias defendidas por ele correspondem à exigência de ter que sugerir um modelo alternativo. Fica absolutamente transparente o quadro teórico kripkeano:

A rough statement of a theory might be the following: $\mathrm{Na}$ initial "baptism" takes place. Here the object may be named by ostension, or the reference of the name may be fixed by a description. When the name is "passed from link to link", the receiver of the name must, I think, intend when he learns it to use it with the same reference as the man from whom he heard it ${ }^{36}$.

33 Ibidem, p. 254.

34 Ibidem, p. 258.

35 Um fato levantado por ele para defender a tese de que os nomes próprios são designadores rígidos é o de que utilizamos os nomes em situaçōes contrafactuais. Essa tese é, de acordo com Kripke "One of the intuitive these I will maintain in these talks is that names are rigid designators. [...] I will argue, intuitively, that proper names are rigids designators." Em situações contrafactuais, usamos os nomes de tal modo que eles se referem ao mesmo objeto que se referem no mundo atual.

Ibidem, p.266. 
O propósito de Kripke, ao apresentar o alcance e os limites da sua proposta alternativa, é a de que o seu quadro causal, dentro do qual trabalha a noção de designador rígido, tenha maior capacidade explicativa do que o Descritivismo e suas variantes, para o fenômeno da nomeação. E, ainda, ao tratar do nome próprio como designador rígido, Kripke não está procurando uma teoria da categoria em questão, mas sim um dispositivo técnico que permita a identificação de um indivíduo em todos os mundos possíveis. Nesse sentido, o autor pondera categoricamente:

Those who have argued that to make sense of the notion of rigid designator, we must antecedently make sense of criteria of transworld identity have precisely reversed the cart and the hors; it is because we can refer (rigidly) to Nixon, and stipulate that we are speaking of what might have happened to him (under certain circumstances), that transworld identifications are unproblematic in such cases $^{37}$.

Embora não se possa afirmar definitivamente que os fundamentos teóricos de Kripke sejam suficientes para superar todas as possíveis dificuldades que se instauram no uso de um nome próprio nos seus mais diferentes empregos, a sua tese de que nomes próprios são designadores rígidos deixa-se comprovar. De fato, essa tese é determinante para a teoria de Kripke e a diferencia claramente da teoria descritivista.

Já no domínio da Linguística, a questão do nome próprio se alia aos estudos da significação - do sentido. No campo da Semântica, é importante a opinião de Lyons ${ }^{38}$, para quem os nomes próprios "não têm sentido, ou um tipo de significação única e especial que os distinga, como classe, dos nomes comuns". Mas, chama a atenção para o fato de "os nomes de pessoas poderem ter uma função vocativa paralelamente a uma função referencial ou quase-referencial no comportamento linguístico".

Podemos ainda destacar o ponto de vista de Bréal ${ }^{39}$, para quem só há uma diferença "intelectual” entre nome próprio e nome comum:

37 Ibidem, p. 259.

38 LYONS, John. Semântica. v. 1. Lisboa: Editorial Presença/Martins Fontes, 1977. p. 183.

39 BRÉAL, Michel. Ensaio de Semântica: ciência das significações. São Paulo: EDUC/Pontes, 1992. p. 126. 
se se classificam os nomes segundo a quantidade de ideias que despertam, os nomes próprios deveriam estar na frente, pois são os mais significativos de todos, sendo os mais individuais. Um adjetivo como augustus, tornando-se o nome de Otávio, sobrecarregou-se de uma quantidade de ideias que lhe eram primeiramente estranhas. Além disso, basta aproximar a palavra César, ouvida do adversário de Pompeu, e a palavra alemã Kaiser, que significa “imperador", para ver o que um nome próprio perde em compreensão para se tornar um nome comum. Donde se pode concluir que do ponto de vista semântico, os nomes próprios são os substantivos por excelência.

Mais contemporaneamente, outro trabalho de destaque é o de Kleiber para quem "le langage a pour vocation première de parler du réel. [...]", sendo que "la fonction de désignation, de représentation, constitue le caractère principal du signe linguistique": nao basta estar no lugar de algo. Dessa maneira, o autor sustenta que "la relation de dénomination est une parite constitutive de cette dimension référentielle. Elle s'inscrit dans le le processus qui met en rapport les signes aves les choses et se place ainsi du côte des relations référentielles [...]"40.

Kleiber estabelece a distinção entre denominação e designação. A primeira se efetua na dependência de uma instauração prévia de um laço referencial particular entre o objeto x e o signo $\mathrm{X}$, como a relação que une uma unidade lexical codificada a seu referente. A segunda, contrariamente às frases de denominação, não pressupóem nenhuma denominação prévia. Além disso, o esquema $\mathrm{X}$ (signo) $\longleftrightarrow \mathrm{x}$ (coisa) pode ser ainda desdobrado em pelo menos duas distinçóes principais: a referência e a denominação. Kleiber assevera ainda que:

avec l'acte de dénomination préable, les noms se restreignent aux seuls signees qui ont été attribués aux choses de la réalité qu'ils désignent. [...] l'établissement d'une règle de fixation référentielle qui permet l'utilisation ultéireure du nom pour l'objet dénommé ${ }^{41}$.

40 KLEIBER, Georges. Dénomination et relations dénominatives. In Langages. Paris: Librairie Larousse, no 76, décembre, 1984. p. 77.

41 Ibidem, p. 81. 
Argumenta que o estatuto exclusivamente referencial atribuído ao nome próprio confronta com as ideias de Mill (1843), à medida que este distingue os nomes quanto à sua significação, enquanto na sua proposta de ordenação das classes dos nomes, concebe o nome próprio como um nome de objeto que não conota nada e que não possui significação, mas sim denota os indivíduos a quem dá o nome, o que não implica qualquer atributo pertencente a esses indivíduos. E mais, o nome próprio possui uma determinada estabilidade enquanto outros nomes têm, geralmente, uma significação ocasional.

\section{Das relações entre antroponímia e toponímia}

As diferenças genéricas que caracterizam o campo de estudos reservado aos dois ramos da Onomástica, quais sejam, Toponímia e Antroponímia, não impedem o encontro, em termos funcionais, dos respectivos objetos de pesquisa. $\mathrm{Na}$ verdade, enquanto os topônimos definem e precisam os contornos de qualquer paisagem terrestre, os antropônimos se referem à distinção dos indivíduos entre si. No entanto, ambos são considerados verdadeiros registros do cotidiano que, em certas circunstâncias, a não ser por meio deles, escaparia às geraçóes futuras.

A Antroponímia pode ser considerada segundo Dick ${ }^{42}$ como um subsistema da Onomástica, dotada de personagens próprios e de processos particulares responsáveis pela ação denominativa propriamente dita. Seu objeto de estudo é sistematizado pelo chamado nome individual (permite distinguir o indivíduo dos demais membros dentro de sua comunidade) e pelo parentesco (define o indivíduo pelos laços de sangue a um grupo familiar).

Essa forma parental é importante socialmente e hoje é chamada de sobrenome. O nome, propriamente dito ou prenome individual, é o resultado do ato de desejo e escolha dos pais ou da família. Os antropônimos estão documentados e registrados, fazendo parte da cultura de todos os povos desde as eras mais primitivas. Apelidos ou nomes foram a forma encontrada para distinguir as pessoas da família e da comunidade, facilitando, assim, a identificação de cada um de seus membros.

42 DICK, Maria Vicentina de Paula do Amaral. A investigação linguística na onomástica brasileira. Estudos de gramática portuguesa III. Biblioteca Luso-brasileira. v.14. Frankfurt am Main,, 2000. p. 217-239. 
$\mathrm{Na}$ Antiguidade, a escolha dos temas dos nomes que motivavam a sua imposição, era feita segundo uma concepção diferente da abordagem moderna. Muitas vezes o nome que o indivíduo recebia era, de acordo com a cultura, a mesma designação para um animal ou a um objeto. $\mathrm{O}$ nome era dado pensando que poderia atrair bons fluidos e repelir espíritos malignos. Com o crescimento das famílias e a população das comunidades, alguns nomes começaram a se popularizar e a serem também usados por descendentes de outras famílias, gerando, assim, dificuldades na distinção de cada pessoa. Houve, então, a necessidade da criação de um segundo nome que acrescentado ao primeiro identificasse melhor as pessoas.

Atualmente percebemos que na sociedade existem nomes adequados às pessoas e aos lugares, embora seja necessário considerarmos que, às vezes, os designativos são escolhidos muito mais pelos modismos do que por qualquer preocupação com o seu verdadeiro significado. Podemos concluir que, a partir de uma mesma matriz lexical da língua (de uma única lexia), formam-se topônimos e antropônimos, assim como se forma um topônimo a partir de um antropônimo, e o contrário.

É oportuno o esquema proposto por Dick ${ }^{43}$, que apresenta as "passagens de um vocábulo pleno, para o uso onomástico - toponímico/antroponímico, seguido ou não, da perda do sentido aparente":

\begin{tabular}{|c|c|c|c|}
\hline $\begin{array}{l}\text { CABRA sdo } 1 . \\
\text { (lat. Capra) } \\
\text { Mamífero } \\
\text { ruminante, a } \\
\text { fêmea do bode } \\
\text { (ABH) } \\
\text { (matriz lexical) }\end{array}$ & $\begin{array}{l}\text { Cabral sdo 1. "lugar onde } \\
\text { há ou pastam cabras". } \\
\text { s.m.der. Cabral, Ossal, } \\
\text { Cerveira revelam a ex- } \\
\text { istência de cabras bravas, } \\
\text { ursos e veados, em épocas } \\
\text { antigas em locais onde } \\
\text { haja estas espécies e que lá } \\
\text { não habitam". }\end{array}$ & $\begin{array}{l}\text { Cabral n.pr. } \\
\text { Antropônimo de } \\
\text { origem familiar; } \\
\text { apelido de família. } \\
\text { "O mais antigo } \\
\text { deste apelido é } \\
\text { Aires Cabral, em } \\
\text { tempo de el-rei D. } \\
\text { Dinis". }\end{array}$ & $\begin{array}{l}\text { Cabral n.pr./ } \\
\text { topônimo. } \\
\text { Serra do Cabral, } \\
\text { (MG), Cabral } \\
\text { (AHMT), baía } \\
\text { Cabral (BA) }\end{array}$ \\
\hline
\end{tabular}

43 DICK, Maria Vicentina de Paula do Amaral. Métodos e Questôes Terminológicas na Onomástica. Estudo de Caso: o Atlas Toponímico do Estado de São Paulo. Investigaçōes Linguistica e Teoria Literária, Recife, v. 9, p. 146, 1999. 
Dick $^{44}$ explicita que "a troca dos campos aplicados não altera, na estrutura básica do vocábulo, a sua carga semântica. Em qualquer das posiçóes citadas (antropônimo, topônimo ou corônimo), a intenção da escolha é a homenagem ao ator que se esconde na forma linguística esvaziada (antropônimo)”.

Como os estudos onomásticos envolvem a função referencial ou denotativa da linguagem, não se pode falar em Onomástica - Toponímia e Antroponímia - sem considerar a questáo da referência. Segundo Seabra ${ }^{45}$, o topônimo e o antropônimo são, pois,

entidades que vão além da expressão linguística e envolvem, obrigatoriamente, os referentes que destacam. Dentro dessa "teoria causal da referência", Oliveira (1996) diz que o nome próprio é um "designador rígido", pois designa um indivíduo de uma maneira única e direta. Mais que isso, acrescentamos que os nomes de lugares, assim como os nomes de pessoas são "designadores rígidos" já que representam ou são os próprios referentes em uma situação de comunicação, podendo-lhes atribuir, por isso, no âmbito dos estudos linguísticos, certa singularidade.

$\mathrm{Na}$ Onomástica, mais especificamente no nome de lugar, a função simbólica ou representativa do topônimo, isto é, o vínculo do significado do nome a determinada localidade ou acidente, indica, necessariamente, que se pergunte o que esse nome simboliza e o que esse nome representa ou denomina. Embora a sociedade sofra mudanças ao longo do tempo, o topônimo permanece na língua, e o sistema de referência extralinguístico pode ou não se perder. Nessa conservação ou perda, a rede referencial se torna opaca, constituindo-se, portanto, uma referência exata: a pessoa identifica alguém ou determinada localidade sem, contudo, atribuir-lhe um significado, preserva o referente, mas não a informação e, assim, os topônimos e antropônimos permanecem na língua.

44 Ibidem, p. 125.

45 SEABRA, Maria Cândida Trindade Costa de. Referência e Onomástica. In: MAGALHÃES, José Sueli de; TRAVAGLIA, Luiz Carlos. (Org.). Múltiplas perspectivas em Linguística. Uberlândia/MG: EDUFU, 2006, v. 1, p. 1956. 
Portanto, frente ao exposto, se considerarmos que, como nome próprio, o topônimo não tem um significado isoladamente, verificaremos que ele conota muito, ao ser utilizado no contexto específico, qual seja, a nomeação de um lugar. Por isso, o topônimo se constitui num signo particular que, na sua gênese, difere de outros signos no que tange a motivação, e sua função é indicar ou identificar um espaço (acidente geográfico) e não significar. É bem verdade que um topônimo só existe porque houve certo momento em que o denominador se deparou com um local que precisava ser nomeado e, nesse particular, consideramos adequado o quadro teórico apresentado por Kripke ${ }^{46}$, uma vez que na situação toponímica também há "um batismo inicial” quando o denominador busca na realidade circundante o nome que melhor se adequa as suas intençôes.

Esse nome circula pela localidade, é ouvido e repetido por várias geraçóes e em diferentes fases da história da localidade. A manutenção desse nome com a mesma referência, a despeito do desaparecimento de sua motivação semântica, faz dele um fóssil linguístico ${ }^{47}$, ou seja, uma expressão linguistico-social que reflete aspectos culturais de um núcleo humano.

Em certos aspectos a teoria de Kripke pode ser aplicada a toponímia, pois os nomes de lugares - topônimos - são "designadores rígidos", que, em uma situação de comunicação, representam ou são os próprios referentes, além de um mesmo nome identificar diferentes lugares, correspondentes a diferentes realidades.

No universo aqui pesquisado, há nomes que são referencialmente identificados pelas pessoas de uma determinada comunidade porque fazem parte da cultura local e, muitas vezes, o significado não é transparente, ou aparentemente o batismo ocorrido é inexplicável, porque diz respeito a aspectos físicos e naturais, e o vínculo denominativo se perdeu com o passar dos anos.

Procurou-se resgatar o significado de vários topônimos das mesorregióes estudadas, e encontrou-se o nome Juca da Mata ${ }^{48}$, embora não seja perceptível o caráter meritório da nomeação. Aplicando a teoria de Kripke, Juca da Mata seria um designador rígido, porque um nome próprio se estabeleceu mediante um

46 Op. cit,. 266.

47 O enunciado "fóssil linguístico" foi uma expressão tomada por Dick (1990a, p.42) ao geógrafo francês Jean Brunes, que o considerava como um "fóssil da geografia humana".

48 Este topônimo nomeia um córrego e uma serra em Adrianópolis, município pertencente à área estudada. 
primeiro ato de denominação (o "batismo" inicial), em que há uma nomeação ostensiva ou a fixaçấo da referência do nome por uma descrição. $\mathrm{O}$ receptor aceitou a referência primeira e a cadeia seguiu, ou seja, o nome passou de elo a elo no grupo social da região e do Estado. E, ainda, qualquer uso posterior do nome remete a essa primeira função denominadora. Ou seja, o nome Juca da Mata chegou até a atualidade não com o seu sentido transparente, mas com a sua referência preservada, embora não se possa localizar o "batismo inicial" aquele em que o denominador elegeu esse nome e não outro para nomear o acidente.

Deve-se considerar que os proponentes da Teoria Causal da Referência chamam a atenção para o fato de o contato com o objeto ser um elemento determinante para a fixação da referência de um nome, ou seja, que o objeto seja considerado como a causa (a fonte ou a origem) de o nome ter uma referência.

Graça (2003, p.195) ${ }^{49}$ defende que a teoria da referência se trata de uma teoria capaz de explicar, "em termos de condições necessárias e suficientes, como é que a referência de um nome é para ser fixada". Para esta autora, a solução para o problema da fixação da referência de tipo causal, é que o objeto seja considerado como a causa (a fonte ou a origem) de o nome ter uma referência. Por vezes, os usos subsequentes (em relação aos primeiros usos) desse nome náo relacionam os falantes diretamente ao objeto referido, e a referência de um termo é explicada a custa de uma cadeia causal apropriada que relaciona indiretamente certo uso do termo ao objeto por ele referido.

O ponto central da teoria é a tese de que os nossos usos de um nome dependem de usos anteriores, e estes, por sua vez, de outros usos mais anteriores, e assim sucessivamente até atingir o ponto em que se encontram os primeiros usos do nome, que ocorrem na presença do objeto, relacionando, diretamente, o nome com o objeto que é o portador do nome. Ainda segundo ela, o nome refere não pela posse de qualquer conhecimento identificador do objeto, que pode ser errado ou insuficiente, mas sim em virtude da existência daquela cadeia causal, constituída pelos diversos usos de um nome, que recua até seus primeiros usos que, por seu turno, fazem a relação do nome com o objeto $^{50}$.

49 GRAÇA, Adriana Silva. Referência e denotação: um ensaio acerca do sentido e da referência de nomes e descrições. Lisboa: Fundação Calouste Gulbenkian, 2003, p. 195.

50 Ibidem, p. 203-204. 
Em síntese, o nome próprio é, para Kripke, o eixo sobre o qual se constroem os enunciados contrafactuais, e isso só é possível porque ele funciona como um designador rígido do objeto real que nomeia, e sobre o qual se constroem os mundos possíveis. Basicamente podemos entender a cadeia causal como constituída por um conjunto de elos que ligam o uso atual de um nome a um uso anterior e assim sucessivamente até o primeiro uso do nome, que é considerado como tendo origem num objeto que é a sua causa (a causa desse primeiro uso).

\section{Considerações finais}

Este estudo teve como propósito apresentar uma reflexão sobre a importância do nome próprio, seja ele aplicado à uma pessoa ou a um lugar. Muito embora os dois termos onomásticos (topônimos e antropônimos) participem da mesma categoria de nome, eles adquirem identidade própria em decorrência da própria natureza do referente nomeado - pessoa ou lugar.

Para a maioria das pessoas o "nome", é apenas "um nome" - essa é a explicação mais casual, mas os signos tornados nomes exigem cuidados de interpretação e reflexão. Confirmamos o que destaca Dick ${ }^{51}$ : "há os que são facilmente compreensíveis, porque o semantismo que sugerem ainda não se cristalizou; outros apresentam dificuldade dupla, seja quanto à origem genética da palavra ou quanto ao significado intrínseco".

Assim, considerando-se o nome próprio como um fato da língua (como um signo linguístico que identifica e guarda uma significação precisa de aspectos físicos ou antropo-culturais), o estudo toponomástico serve como fonte de conhecimento da língua falada numa dada região e como recuperação de fatos físico-geográficos e/ou sócio-histórico-culturais, em parte ou em sua totalidade, por que passaram os povos que habitaram, temporária ou definitivamente uma região.

51 Ibidem, p. 129. 


\title{
REFLECTIONS ABOUT THE QUESTION OF THE PROPER NAME IN THE TOPONOMY
}

\begin{abstract}
An important aspect to be focused on a toponomy study is the nature of the proper name. Subject dealt with in different thought fields, since Aristotle, it suggests investigations which do not pertain to a specific discipline. Thus, we aim at implementing research about the concept of construction of the proper name from philosophical and linguistics perspectives.

KEY WORDS: proper name, toponomy, anthrotoponomy.
\end{abstract}

Recebido em: 28/03/12

Aprovado em: 25/11/12 